\title{
A Fatal Loss of Balance: Dred Scott Revisited
}

\author{
Daniel A. Farber*
}

\section{INTRODUCTION \\ II. DRED SCOTT IN HISTORICAL CONTEXT \\ A. Slavery and Ante Bellum Legal Disputes \\ $B$. The Supreme Court's Intervention in Dred Scott}

III. DRED SCOTT AND LEGAL DOCTRINE

A. Citizenship, Race and the Constitution

B. Narrow Reading of the Enumerated Powers

C. Constitutional Protection for Property Rights

\section{EVAluating DRED SCOTT \\ A. Constitutional Justification \\ B. Legal Process Pathologies \\ C. Practical Impact}

V. DRED SCOTT AND JUDICIAL METHOD

\section{INTRODUCTION}

Dred Scott v. Sandford began as a relatively simple dispute over Scott's status but developed into a complex legal snarl. Scott brought suit in Missouri where he was held as a slave, arguing that he had become free as a result of his former residence with his master in Illinois. ${ }^{2}$ The Supreme Court was initially ready to dispose of the case on relatively narrow grounds. Until the oral argument in the Supreme Court, no issue had been raised as to

* Sho Sato Professor of Law, University of California, Berkeley. This article is part of Pepperdine Law Review's April 1, 2011 Supreme Mistakes symposium, exploring the most maligned decisions in Supreme Court history.

1. 60 U.S. (19 How.) 393 (1857). The case continues to attract interest today, as seen by recent scholarship. See Jack M. Balkin \& Sanford Levinson, Thirteen Ways of Looking at Dred Scott, 82 CHI.-KenT L. REV. 49 (2007); Sarah H. Cleveland, Foreign Authority, American Exceptionalism, and the Dred Scott Case, 82 CHI.-Kent L. REV. 393 (2007); Harry V. Jaffa, Dred Scott Revisited, 31 HARV. J.L. \& PUB. POL'Y 197 (2008); Gerald Leonard, Law and Politics Reconsidered: A New Constitutional History of Dred Scott, 34 LAW \& SOC. INQUIRY 747 (2009).

2. Earl Maltz, DRED SCOTT AND the POlitics of Slavery 102-03 (2007). Factual background on the case is explored in LEA VANDERVELDE, MRS. DRED SCOTT: A LIFE ON SLAVERY'S FRONTIER (2009). 
whether Scott was freed by virtue of living in a territory where Congress banned slavery. ${ }^{3}$ Reversing its course, the majority decided to abandon a narrow decision and instead to resolve the slavery issue once and for all. ${ }^{4}$ The opinion of the Court by Chief Justice Taney took the occasion to rule that free blacks could never become citizens of the United States, that Congress lacked the power to limit slavery in the territories, and that federal legislation limiting slavery anywhere would violate the Due Process Clause. ${ }^{5}$

The late David Currie's biting legal critique of the opinion probably represents the view of most constitutional law scholars today. ${ }^{6}$ As he says, the "variety of feeble, poorly developed, and unnecessary constitutional arguments suggests, if nothing else, a determination to reach a predetermined conclusion at any price."

The Taney opinion also occupies suspect moral ground. Unlike some other judges of the time, Taney was untroubled by the moral dimensions of his judicial support for slavery. Robert Cover's book, Justice Accused, ${ }^{8}$ tells the story of Northern judges forced to carry out a deeply immoral law, the Fugitive Slave Act, by their fidelity to law. In contrast, Chief Justice Taney went far out of his way to leap to the defense of slavery and racism. If many Northern judges were unwilling bridegrooms of evil, Taney can only be considered an ardent suitor. Consistent with the biblical maxim that he who sows the wind shall inherit the whirlwind, ${ }^{9}$ Taney's opinion may well have been a contributing factor in bringing about the bloodiest of America's wars and the destruction of slavery. ${ }^{10}$

Dred Scott has been the subject of scrutiny for over a century and a half, including some exceptional works of historical scholarship and a recent group of revisionist defenders. This brief essay will not attempt to synthesize, let alone survey, that scholarship, nor will it dwell on the details of the decision. Instead, it will limit itself to a few key points.

Part II puts the opinion in historical context. In political terms, the case involved the explosive issue of slavery in the territories. In constitutional terms, it raised complex issues about Congress's regulatory power over the territories, the status of free blacks, and whether slavery was a portable status or relied for its existence on local law. Taney's opinion reflected the increasingly strident Southern view of these issues.

3. See Don E. Fehrenbacher, The DRED SCOTt CASE: ItS Significance in AMERICAN LAW AND POLITICS 288 (1978).

4. See infra notes 29-31 and accompanying text.

5. See infra note 28 and accompanying text.

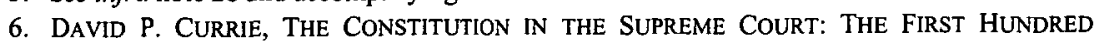
YEARS, 1789-1888, at 263-72 (1985).

7. Id. at 272.

8. RoBert M. COVER, JustiCE ACCUSED: ANTISLAVERY AND THE JUdiCIAL PROCESS (1975).

9. Hosea 8:7.

10. See infra notes $134-41$ and accompanying text. 
Part III discusses three aspects of the opinion: its effort to ensure that blacks could never be citizens, let alone equal ones; its deployment of a "limited government" argument for a narrow interpretation of Congress's enumerated power over the territories; and its path-breaking defense of property rights against government regulation. These constitutional tropes of racism, narrowing of federal power, and protection of property were to remain dominant in constitutional law for another seventy-five years. The Court did not give up its quest to limit congressional power in the interest of property rights until the New Deal. ${ }^{11}$ Indeed, it was not until Brown v. Board of Education, ${ }^{12}$ nearly a century after Dred Scott, that one could truly say that the American legal system had repudiated Taney's legacy of racism.

At the risk of gilding the lily, Part IV explains why Dred Scott deserves a unique place of infamy in American constitutional law. Dred Scott exemplified the collapse of efforts to find common ground between contending factions and, in particular, the growing insistence of Southerners on the need for absolute assurances about the safe future of slavery. Apart from the failings of the opinion itself, Dred Scott also represents an extraordinary case of presidential intrusion into the judicial process and a breakdown in fair procedure within the Court itself. We can never know whether a more measured decision would have forestalled the conflict that led to the deaths of 800,000 Americans, but it can at least be said that the Court did nothing to inject common sense or balance into the national debate. Throwing more fuel on the fire is seldom the best way to avoid an explosion.

Part V closes with some reflections about the implications of Dred Scott for judicial methodology. Taney's exercise in originalist constitutional interpretation highlights some pitfalls that present-day originalists would do well to avoid. Taney's effort to read all of the Constitution through a states' rights, pro-slavery lens also dramatizes the risks of foundationalism. Taney's opinion lacks any sense of balance-a failing at any time for a judge, but particularly dangerous when the nation is poised over a historic abyss. To use a different metaphor, never has a judge gambled so badly for such high stakes.

11. See, e.g., Wickard v. Filburn, 317 U.S. 111, 131 (1942) (finding that the Court could not enjoin congressional regulation of local intrastate activities that affect interstate commerce).

12. 347 U.S. 483 (1954). 


\section{DRED SCOTT IN HISTORICAL CONTEXT}

Like any judicial decision, Dred Scott cannot be fully understood outside of its historical context. Part A briefly reviews some key aspects of the disputes over slavery that culminated in Dred Scott and later led to civil war. The uneasy legal and political status of slavery in the early years of the Republic had become a much more polarized dispute by the 1850 s. As a prelude for the remainder of this essay, Part B provides a sketch of the Dred Scott decision itself. Even a century and a half later, it is startling to see how many fundamental constitutional issues Taney reached out to unnecessarily decide. The closing pages of the opinion show that routine application of res judicata (holding the state court's judgment against Scott to be binding) or choice-of-law doctrines (applying Missouri law to the dispute) would have sufficed to dispose of the case. Instead, Taney reached out to brand blacks as eternally unequal to the legal status of whites and to bar any effort by Congress to control the spread of slavery.

\section{A. Slavery and Ante Bellum Legal Disputes}

To put Dred Scott in context, some understanding of pre-Civil War legal thought is needed. While it is true that the Constitution provided some protections for slavery, early American jurists did not regard the "peculiar institution" with any great enthusiasm. Justice Story condemned slavery as immoral and argued that "every doctrine, that may be fairly deduced [from] ... the nature of moral obligation, may theoretically be said to exist in the law of nations; and unless it be relaxed or waived by the consent of nations, ... it may be enforced by a court of justice." 13 He concluded that a slave ship is guilty of piracy under international law, except when the flag state permits the slave trade. Similarly, in In re Antelope ${ }^{14}$ Chief Justice Marshall began with this premise concerning the slave trade:

That it is contrary to the law of nature will scarcely be denied. That every man has a natural right to the fruits of his own labour, is generally admitted; and that no other person can rightfully deprive him of those fruits, and appropriate them against his will, seems to be the necessary result of this admission. ${ }^{15}$

13. United States v. La Jeune Eugenie, 26 F. Cas. 832, 846 (C.C.D. Mass. 1822). For background on this case, see ROBERT M. COVER, JUSTICE ACCUSED: ANTISLAVERY AND THE JUDICIAL PROCESS 100-16 (1975).

14. 23 U.S. $66(1825)$.

15. Id. at 120 . 
Marshall found, however, that the practice of nations fell lamentably short of this standard and hence that the slave trade did not violate international law. ${ }^{16}$

Story also provided a clear explanation regarding the extraterritorial effect of slavery laws:

Suppose a person to be a slave in his own country, having no personal capacity to contract there, is he, upon his removal to a foreign country, where slavery is not tolerated, to be still deemed a slave? If so, then a Greek or Asiatic, held in slavery in Turkey, would, upon his arrival in England, or in Massachusetts, be deemed a slave, and be there subject to be treated as mere property, and be under the uncontrollable despotic power of his master. The same rule would exist as to Africans and others, held in slavery in foreign countries. ${ }^{17}$

Slavery, Justice Story continued, was a personal status and one that required affirmative support from local law:

But we know, that no such general effect has in practice ever been attributed to the state of slavery. There is a uniformity of opinion among foreign jurists, and foreign tribunals, in giving no effect to the state of slavery of a party, whatever it might have been in the country of his birth or of that, in which he had been previously domiciled, unless it is also recognized by the laws of the country of his actual domicile, and where he is found, and it is sought to be enforced. ${ }^{18}$

Story also explained that English law adopted the same result:

This is also the undisputed law of England. It has been solemnly decided, that the law of England abhors, and will not endure, the existence of slavery within the nation; and consequently, as soon as a slave lands, in England, he becomes ipso facto a freeman; and discharged from the state of servitude. Independent of the

16. Id. at 120-21.

17. JOSEPH STORY, COMMENTARIES ON THE CONFLICT OF LAWS, FOREIGN AND DOMESTIC $\$ 96$ (Edmund Hastings Bennett ed., 5th ed. 1857) (citations omitted) [hereinafter STORY]. For further discussion of Justice Story's perspective, see Christopher L.M. Eisgruber, Justice Story, Slavery, and the Natural Law Foundations of American Constitutionalism, 55 U. CHI. L. REV. 273 (1988).

18. STORY, supra note $17, \S 96$. 
provisions of the Constitution of the United States, for the protection of the rights of masters in regard to domestic fugitive slaves, there is no doubt, that the same principle pervades the common law of the non-slave-holding States in America; that is to say, foreign slaves would no longer be deemed such after their removal thither. ${ }^{19}$

This position ultimately derived from Lord Mansfield's famous statement that: "The state of slavery is of such a nature, that it is incapable of being introduced on any reasons ... but only [by] positive law ... : it's so odious, that nothing can be suffered to support it, but positive law." 20

A wealth of American cases supported the view that slavery could exist only when supported by local, positive law (that is, legislation). Until just before the Civil War, this position was taken even by Southern courts. In cases where slaves had been brought to free states for more than a brief sojourn, Southern courts generally ruled that they remained free even on their return to slave states. Under that rule, Dred Scott would have been entitled to freedom. Only in the final years before the war did this position change. Indeed, in the state court litigation involving Dred Scott, the Missouri Supreme Court engaged in just such an about-face, announcing that it would no longer follow earlier decisions that gave comity to Northern laws banning slavery for long-term residents. ${ }^{21}$

Perhaps it was fitting that Missouri would later be the scene of the Dred Scott litigation, because decades earlier it had already become pivotal in slavery disputes. By 1820 , Missouri's effort to join the Union had led to a crisis, ending with the compromise solution of limiting future expansion of slavery north of a line drawn at $36^{\circ} 30^{\prime} 00^{\prime \prime} \mathrm{N}$. The battle over the extension of slavery to new territories was reignited by the war with Mexico. Some Northerners argued that Congress had the power to forbid slavery in the territories, as had been done in the old Northwest Ordinance before the Constitution was even adopted. Led by John C. Calhoun, some Southerners responded that the territories were held in trust by the federal government on behalf of all the states, and that discriminating against the institutions of the slave states would be unconstitutional. Calhoun's theory was later embraced by Taney's opinion. By 1849, some Southern states were threatening secession if the Wilmot Proviso banning slavery in the newly acquired territories was adopted. But the crisis was defused by the Compromise of 1850 , designed by Henry Clay but actually pushed through Congress by Stephen A. Douglas. By assembling separate coalitions on different parts of

19. Id.

20. Somerset v. Stewart, (1772) 98 Eng. Rep. 499 (K.B.) 510. Today Lord Mansfield is considered one of the great creators of modern commercial law.

21. See Scott v. Emerson, 15 Mo. 576 (1852). 
the compromise, Douglas obtained passage of a package that included something for each side. For the North, the Compromise admitted California as a free state and abolished the slave trade in the District of Columbia. For the South, it strengthened the Fugitive Slave Act and created the New Mexico and Utah territories without the Wilmot Proviso. ${ }^{22}$

The story of the 1850s is in large part the saga of how this apparent settlement of the slavery issue came unglued. In the process, the conflict destroyed the Democratic Party as a national institution, taking Stephen Douglas along with it. It also created the Republicans as a sectional party, ultimately leading to Lincoln's election. The combined effect was to produce Lincoln's election and the secession crisis. The process was incredibly complicated, but we can focus on three major contributing factors. $^{23}$

First, enforcement of the Fugitive Slave Act horrified many Northerners. The spectacle of escaped slaves being dragged away in manacles roused public opinion against slavery. The number of slaves who escaped to the North was quite small, and even fewer were ever returned under the Act. For a statute whose value to slave owners was largely symbolic, the South paid a heavy price in Northern anger and resentment. ${ }^{24}$

Second, Douglas unwittingly reignited the issue of slavery in the territories with his Kansas-Nebraska Act. Douglas was eager to organize these territories in order to pave the way for settlement and a transcontinental railroad. By adopting "popular sovereignty," which left control of the slavery decision to the territorial legislature, Douglas hoped to finesse the slavery issue and keep it off the national agenda. His tactic backfired. Northerners were appalled by the repeal of the Missouri Compromise. Implementation of the statute was also a disaster. Kansas became the scene of bloodshed as rival groups of Northerners and Southerners vied for control. Worse, the Buchanan Administration broke its pledges and endorsed the fraudulent, pro-slavery Lecompton Constitution for Kansas. This was intolerable to Douglas, who broke with the Administration. When Buchanan threatened to destroy him politically,

22. See David M. PotTer, The IMPEnding CRisis: $1848-1861$, at $18-23,53-62,88-89,108$, 113-16 (Don E. Fehrenbacher ed., 1976).

23. For a comprehensive historical review of the issue of slavery in the territories, see MICHAEL A. MORRISON, SLAVERY AND THE AMERICAN WEST: THE ECLIPSE OF MANIFEST DESTINY AND THE COMING OF THE CIVIL WAR (1997).

24. See POTTER, supra note 22, at 132-37; see also 1 ALlAN NEVINS, THE EMERGENCE OF LINCOLN: DOUGLAS, BUCHANAN, AND PARTY CHAOS, 1859-1861, at 229-304 (1950) [hereinafter 1 Nevins]; 2 Allan Nevins, The Emergence of Lincoln: Prologue to Civil War, 1859-1861, at 30-31, 115, 488-89 (1950) [hereinafter 2 NEVINS]; KENNETH M. STAMPP, THE IMPERILED UNION: ESSAYS ON THE BACKGROUND OF THE CIVIL WAR 237 (1980). 
reminding him that Jackson had destroyed his own opponents within the Democratic Party, Douglas was not impressed. "Mr. President," he replied, "I wish you to remember that General Jackson is dead."25 But despite this bravado, Douglas had to fight for his political life against Buchanan. The schism between the two men badly damaged the Democratic Party in the North, thereby strengthening the emerging Republican Party. ${ }^{26}$ In Dred Scott, by holding that the people of a territory had no power to restrict slavery, Chief Justice Taney intervened on the side of Buchanan. This was perhaps intentional, for as we will see later, Buchanan actively involved himself in the Court's deliberations.

\section{B. The Supreme Court's Intervention in Dred Scott}

Dred Scott's claim to freedom was based on his sojourn in Illinois and in the Minnesota Territory, where slavery was banned. Chief Justice Taney's opinion for the Court had two major holdings. First, even if Scott was free, blacks could never become citizens of the United States (nor, for federal constitutional purposes, of the states where they lived). Second, Congress lacked the power to ban slavery in the territories, making the Missouri Compromise unconstitutional along with the basic platform of the Republican Party. Because several concurring opinions were filed, historians still dispute just what parts of Taney's opinion had the support of a majority of the Justices. As discussed later, Buchanan had not only been informed about the opinion prior to its release but played an active role in bringing one key Justice into the majority. Despite the Court's hopes of finally putting the vexing issue of slavery to rest, its opinion had the opposite effect. $^{27}$

There was no need for the Court to have even considered these broad arguments. As Justice Nelson's concurring opinion pointed out, Taney could have applied earlier precedent and held that Missouri law controlled Dred Scott's legal status on his return to that state. ${ }^{28}$ Indeed, Nelson was

25. 1 NEVINS, supra note 24, at 253.

26. See POTTER, supra note 22, at 158-59, 199-224, 297-325; see also 2 ALlAN NEVINS, ORDEAL OF THE UNION: A HOUSE DIVIDING, 1852-1857, at 78-159, 301-46 (1947); KENNETH M. STAMPP, AMERICA IN 1857: A NATION ON THE BRINK 144-81, 257-331 (1990).

27. Don E. Fehrenbacher's The Dred Scott Case: Its Significance in American Law and Politics is a classic treatment of the historical context, legal complexities, decisional process, and impact of the case. FEHRENBACHER, supra note 3. It is more readily available in an abridged paperback, DON

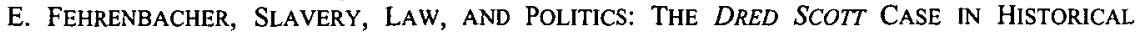
Perspective (1981). Another useful treatment is PAUl FInKelman, DRED SCOTT V. SANDFORD: A BRIEF HISTORY WITH DOCUMENTS (1997), which also contains excerpts from the long, meandering opinions and reprints the responses of Northern and Southern papers to the decision. For a brief introduction to the case and its effects, see RICHARD H. SEWELl, A HOUSE DIVIDED: SECTIONALISM AND CIVIL WAR, 1848-1865, at 57-61 (1988).

28. Dred Scott v. Sandford, 60 U.S. (19 How.) 393, 457-63, 465 (1857) (Nelson, J., concurring). 
originally assigned to write an opinion for the Court on this very ground. ${ }^{29}$ But deciding the case on that basis would have deprived Taney of the opportunity to carve white supremacy into constitutional stone and to strike a blow for the slave states against the North.

In the last two pages of the opinion, Taney added yet another ground for reversal—one which would seemingly obviate the rest of the opinion: Dred Scott had already lost in the state courts, and the judgment there disposed of the controversy and was binding in federal court. ${ }^{30}$ That would have seemed to require a straightforward application of res judicata, an argument that any first year law student would be expected to apply on a civil procedure exam. Thus, finally - after sixty pages of rambling exegesis on constitutional issues-Taney got around to an argument that makes clear legal sense. Of course, if he had started and ended with that point, there would have been no need for the rest of the opinion, and the case would be unknown today except perhaps to a few civil procedure specialists.

\section{DRED SCOTT AND LEGAL DOCTRINE}

Chief Justice Taney's legal analysis deserves attention given the historic importance of the case. It also deserves attention because of its foreshadowing of Lochner-era constitutional jurisprudence. It was the first Supreme Court decision to endorse white supremacy as a constitutional norm, the first to strike down a law of Congress on federalism grounds, and the first to use the Due Process Clause to entrench the economic status quo. Thus, it was an initial foray into legal ground later to be occupied by opinions such as Plessy v. Ferguson ${ }^{31}$ (upholding racial segregation), Champion v. Ames ${ }^{32}$ (holding on federalism grounds that Congress could not ban child labor), and Lochner v. New York ${ }^{33}$ (striking down labor laws that protected employees).

The point is not that these later judges consciously or unconsciously adopted Dred Scott's reasoning. No doubt many of them would have been horrified by the suggestion. Rather, they may well have rediscovered independently how conveniently such arguments could be used to defeat efforts to regulate economic relations, whether between masters and slaves or employers and employees. Taney deserves credit, if that is the right term,

\footnotetext{
29. FEHRENBACHER, supra note 3, at 306-07.

30. Dred Scott, 60 U.S. (19 How.) at 454.

31. Plessy v. Ferguson, 163 U.S. 537 (1896), overruled by Brown v. Bd. of Educ., 347 U.S. 483 (1954).

32. Champion v. Ames, 188 U.S. 321 (1903).

33. Lochner v. New York, 198 U.S. 45 (1905).
} 
for his prescience in mapping out a course for conservative jurisprudence over the next seventy-five years.

Part A will consider what is, to modern readers, the most offensive portion of the opinion: the racism that Taney claims belonged to the earlier era of the Framers but obviously reflects his own deep-seated prejudices. Part B turns to the tortured interpretation of Congress's enumerated power over the territories, while Part C examines Taney's use of the Due Process Clause.

\section{A. Citizenship, Race and the Constitution}

A key issue in Dred Scott-or at least an issue that Taney chose to confront-is the relationship between state and federal citizenship. It is important to begin by understanding the general confusion that existed on this score up to the Civil War. The question of "whether the Revolution had created one community of allegiance or many" remained unresolved. ${ }^{34}$ Just three weeks after the Declaration of Independence, the Continental Congress passed a resolution providing that "all persons residing within any of the United Colonies, and deriving protection from the laws of the same, owe allegiance to the said laws, and are members of such colony." 35

The states quickly adopted their own naturalization laws, ${ }^{36}$ but their power over citizenship was a source of confusion because each state's citizens became entitled to equal treatment in all other states under the Articles of Confederation's precursor to what is now the Article IV Privileges and Immunities Clause. ${ }^{37}$ According to Kettner, who remains the leading authority on the history of citizenship before the Civil War, "Although the primary locus of allegiance throughout the Confederation period was still in the individual sovereign state, the idea that citizens belonged to a larger national community surfaced frequently, never fully articulated or theoretically explored, but persuasive-almost instinctive-in certain contexts." 38 For instance, it was unclear whether a person who had been naturalized by a state under the Articles was thereby a citizen of the United States for purposes of qualifying to sit in the United States Senate. ${ }^{39}$ Notably, naturalization could proceed through treaties with Indians or as part

34. James H. KetTNer, The Development of AMERICAN Citizenship, 1608-1870, at 209 (1978).

35. Id. at 179 .

36. Id. at 214-19.

37. Id. at 220 .

38. Id. at 224 .

39. Id. at 234-35. For an overview of immigration policy prior to the Constitution, see James E. Pfander, Reclaiming the Immigration Constitution of the Early Republic: Prospectivity, Uniformity, and Transparency, 96 VA. L. REV. 359, 371-85 (2010). 
of the admission of a new state (as in the case of Texas and Louisiana) ${ }^{40}$ It was clear from a variety of treaties and statutes that Indians as well as whites could become citizens-thus, it is an oversimplification to identify citizenship with whiteness. ${ }^{41}$

The connections between citizenship, allegiance, and government protection went back in English law at least to the time of Lord Coke, during the reign of James I. Coke was faced with such issues in the context of determining the rights of citizens of Scotland under English law. ${ }^{42}$ James was king of both England and Scotland, but they had separate parliaments so it was not clear how their citizenships related. Fundamental to Coke's analysis was the proposition that the "bond between the subject and the sovereign ... involved reciprocal obligations" of allegiance and protection that attached at birth. ${ }^{43}$

The predominant Southern theory-although not the theory that Southerners found convenient in the context of Dred Scott-was that citizenship stemmed from the states. Based on the theory that individual allegiance flowed fundamentally to the states, the Confederacy maintained that no change in allegiance took place at secession. Thus, unlike the American Revolution, where individuals were considered to have a period in which to choose allegiance, the allegiance of Southerners automatically remained with the existing states when those state governments chose to sever their own relationship with the federal government. ${ }^{44}$ A similar situation would arise today if the United States decided to leave the United Nations or NATO; such a decision would clearly have no effect on the status of U.S. citizens. Thus, Southerners who, following secession, decided to side with the North were guilty of treason, while colonists who sided with the British were not guilty of treason provided they made their decision promptly and openly. ${ }^{45}$

During the nullification crisis, South Carolina insisted that "[t]he allegiance of the citizens ... is due to the ... State, and ... obedience only, and not allegiance, is due ... to any other power or authority, to whom a controul over them has been or may be delegated by the state. ${ }^{, 46}$ The state legislature then passed a law requiring all militia officers to swear that they

\footnotetext{
40. KETTNER, supra note 34, at 251-53.

41. Id. at 292 .

42. Id. at $16-17$.

43. Id at 18 .

44. Id. at 335 .

45. Id.

46. Id. at 265 .
} 
had "faithful and true allegiance" to the state. 47 The law was held unconstitutional by the state appellate court, with a dissenting nullifier arguing that only the state government could command a citizen's ultimate allegiance. $^{48}$ Southerners also argued that a national statute governing expatriation (abandonment of citizenship) would be unconstitutional because it was not within any express Congressional power, leaving the matter to the states. ${ }^{49}$ As a U.S. Representative from Virginia put it, "The relation to the State government was the basis of the relation to the General Government, and therefore, as long as a man continues a citizen of a State, he must be considered a citizen of the United States."

Thus, the relative priorities of federal and state citizenship were matters in some dispute. The dominant Southern theory was that state citizenship was paramount, but in the context of Dred Scott this would have led to the unpalatable conclusion that the status of blacks as citizens in Northern states would have been entitled to recognition in Southern states.

Taney's opinion contended that the Framers considered blacks "as a subordinate and inferior class of beings, who had been subjugated by the dominant race, and, whether emancipated or not, yet remained subject to their authority, and had no rights or privileges but such as those who held the power and the Government might choose to grant them."51 Justice Daniels managed to exceed even Taney's level of offensiveness with his dictum: "That in the establishment of the several communities now the States of this Union, and in the formation of the Federal Government, the African was not deemed politically a person." 52 Note, however, that the Constitution refers to slaves as "person [s] held to service," as Justice McLean pointed out. ${ }^{53}$ It is also significant that Indians had long been held eligible for citizenship and that some Southern courts had held that free blacks automatically became state citizens. $^{54}$ Moreover, an 1803 federal statute banned ships from bringing any black into the country who was not "a native, a citizen, or registered seaman of the United States." 55

In addition to this federalism question regarding citizenship, Dred Scott held that there was a racial exception to the normal rule of birthright U.S. citizenship. There is no doubt that in the Civil War era racism was widespread, even in the North. For many, the issue was not so much an objection to slavery as a desire to keep all blacks out of the territories.

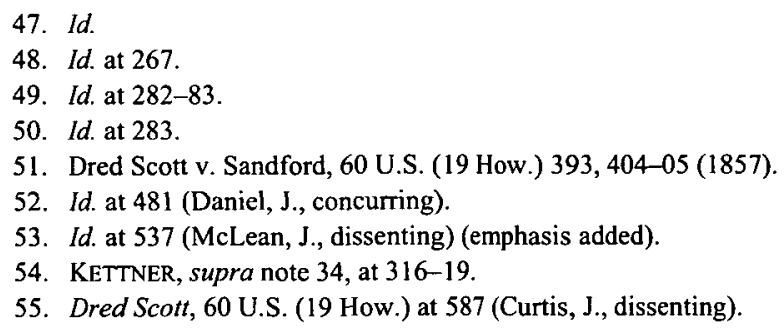


[Vol. 39: 13, 2011]

A Fatal Loss of Balance

PepPerdine Law ReVIEW

Moreover, many Republicans repeatedly found it necessary to reaffirm publicly their disinclination toward miscegenation and their belief in white supremacy. Savvy politicians like Lincoln were careful not to offend racist audiences. This was a constant theme in the Lincoln-Douglas debates, most notably in the Charleston, Illinois debate where Lincoln denied being "in favor of bringing about in any way the social and political equality of the white and black races." ${ }^{, 56}$ So Taney was certainly appealing to widespread racism with his racial characterization of citizenship.

McLean also pointed out that Taney's historical exegesis was remarkably one-sided: "[W]hile I admit the government was not made especially for the colored race, ... many of them were citizens of the New England States, and exercised the rights of suffrage when the Constitution was adopted ...."57 This may not prove that they were regarded as U.S. citizens, but it does rebut Taney's assertion that blacks were incapable of being members of the political community or of having legal rights that others were required to accept.

One reason for the relative paucity of evidence of the Framers' definition of citizenship is that they were rarely required to consider it. Citizenship is an important legal concept, but not necessarily decisive in a broad range of contexts. In many respects, personhood is the more important concept under the U.S. Constitution. In the Constitution itself, citizenship's main significance is as a job qualification for elected federal office. But there is no requirement of citizenship for appointed office as a member of the judiciary or the Cabinet, nor any limitation of the franchise to citizens. Article I, Section 2, Clause 1 provides that voters for House members "have the Qualifications requisite for Electors of the most numerous Branch of the State Legislature," so blacks could vote in federal elections if they could vote in state ones. ${ }^{58}$ Under Article I, Section 3, Clause 1, members of the Senate are chosen by state legislatures, with no stated restriction on who could serve in such a legislature. ${ }^{59}$ Otherwise, the term "citizen" shows up only in Article III's definition of diversity jurisdiction ${ }^{60}$ and in Article IV's Privileges and Immunities Clause. ${ }^{61}$ Only in these two clauses is state citizenship rather than federal citizenship invoked. And despite Taney's restriction of Article III diversity jurisdiction

\footnotetext{
56. See DON E. FEHRENBACHER, LINCOLN IN TEXT AND CONTEXT: COLLECTED ESSAYS 101 (1987) (discussing Lincoln's views on race).

57. Dred Scott, 60 U.S. (19 How.) at 537 (McLean, J., dissenting).

58. U.S. CONST, art. I, $\S 2$, cl. 1 .

59. U.S. CoNST. art. I, $\S 3$, cl. 1 .

60. U.S. CONST. art. III, $\S 2, \mathrm{cl} .1$.

61. U.S. CoNST. art. IV, $\S 2$, cl. 1.
} 
to whites, there was no apparent constitutional barrier to blacks bringing suit under admiralty or federal question jurisdiction.

Other portions of the Constitution involve personhood rather than citizenship. Article III, Section 2, Clause 3 provides a right to a jury in the "Trial of all Crimes, except in Cases of Impeachment," without reference to citizenship. ${ }^{62}$ Article I, Section 9, Clause 3 prohibits bills of attainder and ex post facto laws without any reference to the citizenship of the defendant. ${ }^{63}$ Some provisions of the Bill of Rights refer to "the people," which by Taney's reasoning might not have included blacks. But the Fifth and Sixth Amendments, governing due process and criminal procedure, are not so limited, nor is the right to jury trial in civil cases of the Seventh Amendment. Because Taney viewed the Fifth Amendment Due Process Clause as protecting substantive rights of liberty and property, free blacks were clearly entitled to this basic constitutional protection, at least if constitutional text means anything at all.

Taney's argument about citizenship seems ungrounded in constitutional text, judicial precedent, or standard constitutional historical sources such as Madison's convention notes or the Federalist Papers. It is based on speculation about what the Framers might have intended. Don Fehrenbacher remarked that Taney's "language often tended to become most dogmatic when his argument became most dubious," and that "[h]e sometimes used a phrase such as "too plain for argument' to introduce an assertion flagrantly contrary to fact." ${ }^{\prime \prime 4}$ This was surely true in Dred Scott.

Much of Taney's opinion consists of speculation about what the Framers must have thought despite the lack of any specific evidence to that effect. For instance, he argued that Southerners could not have meant to allow Northern blacks any rights under the Privileges and Immunities Clause and therefore must not have intended that they qualify as citizens of the Northern states. Taney offers no direct evidence of pre-ratification discussion of the clause to support this contention. A more relevant indication of intent, as Justice Curtis observed in dissent, is the rejection of a proposal by South Carolina to limit the Privilege and Immunities Clause's predecessor in the Articles of Confederation to whites. ${ }^{65}$

Historians, by and large, have not found Taney's speculation persuasive: "Obviously, Taney was reading southern apprehensions of the 1850 s back into the minds of southerners in 1787 , forgetting his earlier assertion that free Negroes were then so few in number that they 'were not even in the

\footnotetext{
62. U.S. CONST, art. III, $\S 2, \mathrm{cl} .3$.

63. U.S. CONST. art. I, $\$ 9$, cl. 3.

64. FEHRENBACHER, supra note 3, at 268-69.

65. Dred Scott v. Sandford, 60 U.S. (19 How.) 393, 575-76 (1857) (Curtis, J., dissenting).
} 
minds of the framers of the Constitution." ${ }^{\prime 66}$ In any event, Taney offers nothing that speaks to what the Framers might have thought about diversity jurisdiction, and the purposes of diversity jurisdiction clearly support allowing disputes between free blacks inhabiting one state and citizens of some other state the benefit of a forum unbiased by local loyalties.

The definition of citizenship for purposes of diversity jurisdiction was clearly understood to be a distinctive question in Taney's time: corporations chartered in a state qualified as state citizens for diversity purposes, ${ }^{67}$ but obviously no one thought this made them citizens of the United States for purposes of holding federal office. Taney's argument reflects what he viewed as the unacceptability to the Framers of treating slaves as citizens for purposes of the Privileges and Immunities Clause, but had little or no relevance to defining citizenship for purposes of diversity jurisdiction. For instance, he argued that if free blacks were treated as citizens and entered a Southern state, the results would have been horrendous and unacceptable:

It would give to persons of the negro race ... the right to enter every other State whenever they pleased, singly or in companies, without pass or passport ... to go where they pleased at every hour of the day or night without molestation, ... and it would give them the full liberty of speech ... and to keep and carry arms wherever they went. And all of this would be done in the face of the subject race of the same color, both free and slaves, and inevitably producing discontent and insubordination among them, and endangering the peace and safety of the State.

It is impossible, it would seem, to believe that the great men of the slaveholding States, who took so large a share in framing the Constitution of the United States, and exercised so much influence in procuring its adoption, could have been so forgetful or regardless of their own safety and the safety of those who trusted and confided in them. ${ }^{68}$

66. FEHRENBACHER, supra note 3, at 355-56 (quoting Dred Scott, 60 U.S. (19 How.) at 411-12).

67. Louisville, Cincinnati, \& Charleston R.R. Co. v. Letson, 43 U.S. (2 How.) 497, 558 (1844). Given this decision, despite Dred Scott, a black could have gotten into federal court by conducting business affairs through a wholly owned corporation. Indeed, blacks theoretically could have litigated their status by getting a wholly owned corporation chartered, contracting with the corporation for their services, and then having the corporation sue the putative owner for interfering with the execution of the labor contract.

68. Dred Scott, 60 U.S. (19 How.) at 417. 
The logic of this passage deserves unpacking:

1. If the status of free blacks as citizens was determined by the laws of the state where they resided, then this must apply not only to the Diversity Clause but to the Privileges and Immunities Clause.

2. When free blacks visited a Southern state, perhaps because there was no correlative class of free black citizens in that state, they would necessarily have the same rights as all other (white) citizens, including the right to bear arms, etc.

3. This would pose a grave threat of sparking a slave insurrection.

4. The Southern participants in the adoption of the Constitution must have known this, so they could not have possibly consented to such an interpretation of the Privileges and Immunities Clause.

5. Hence, the Diversity Clause cannot be construed to allow citizenship to be determined by state law.

Every step of this reasoning is contestable, but as is often the case, the whole argument is driven by the unstated assumption at the beginning. The key move is equating "diversity" citizenship with "privileges and immunities" citizenship.

Shifting the focus from privileges and immunities to diversity jurisdiction not only eliminates the basis for Taney's argument but suggests some strong arguments against excluding blacks from citizenship. Indeed, the same kind of logic used by Taney could be used to derive a contrary conclusion about diversity citizenship. Based on reasoning similar to Taney's, we could argue that Southern whites would surely have rejected Taney's reading of the Diversity Clause to exclude free blacks at the time of the Framing. The reason is that, although Taney's reading of the Diversity Clause worked to Dred Scott's disadvantage in this particular case, it also resulted in giving free blacks a special exemption from being subjected to federal diversity jurisdiction. If a Southerner wished to sue a Northern white, the Southerner could bring suit in a Northern federal court rather than being relegated to the potentially biased state court. But if he wished to sue a Northern black, he would have to give the black the home court advantage of a state forum. Similarly, if a Southerner owned property in the North and was subjected to a quasi in rem suit by a Northern white, the Southerner could remove to federal court, but he would lack the ability to do so if sued by a Northern black. Surely the Framers of the Constitution did not expect blacks to enjoy this special privilege!

Whatever the Framers expected to be the status of free blacks under state law or federal legislation, there is no direct evidence that they viewed the Constitution as precluding them from becoming citizens, particularly given the fact that in five states blacks were entitled to vote for the members of the convention ratifying the Constitution. ${ }^{69}$ There is also little evidence

69. See id. at 576 (Curtis, J., dissenting). 
that the legal system recognized any other category besides citizens and those holding allegiance to other sovereigns (whether foreign or an Indian tribe). For instance, the Eleventh Amendment prohibits suits against a state by "Citizens of another State, or by Citizens or Subjects of any Foreign State,"70 without any third category of "non-citizen subjects of the other state." Given the absence of any other legal category and the obvious fact that blacks were not subjects of any foreign power, it is hard to see how the Framers' conceptual framework allowed free blacks to be anything other than citizens. ${ }^{71}$

Revisionists argue that "the persistent strand of white nationalism in American politics provides strong support for Taney's claim that most persons responsible for the Constitution thought that Dred Scott was not and could not become a citizen of the United States., ${ }^{, 72}$ Even if the Framers assumed that blacks would not be United States citizens, relying on such expectations as a basis for constitutional interpretation can be a slippery process. Undoubtedly, the Framers would also have expected that no black could be a federal judge, member of Congress, or Cabinet member. It is more certain that they did not expect women to hold national office, but that assumption does not make male sex a prerequisite for the Presidency, the Senate, or the Supreme Court. They probably also assumed that interstate commerce would involve land or sea rather than air transportation. To translate the Framers' alleged expectations about black exclusion from citizenship into a constitutional rule, Taney needed an argument linking the two that is simply absent from the opinion.

But all of this is much too legalistic. Taney was not really making a legal argument about the original understanding of the term "citizenship." Most of his evidence was at most tangentially relevant to that issue of legal terminology. His argument was that blacks were outside the social compact entirely at the time of the Framing. For instance, Taney was at pains to establish that blacks were not covered by the Declaration of Independence's proclamation that "all men are created equal," and "endowed by their Creator with certain unalienable rights." constitutional argument, but supported Taney's real point, which is that blacks are outside of the social compact and for that reason barely qualify as persons, let alone citizens.

70. U.S. CONST. amend. XI.

71. Cf. State v. Manuel, 20 N.C. (3 \& 4 Dev. \& Bat.) 144 (1838) ("According to the laws of this State, all human beings within it, fall within one of two classes, to wit, aliens and citizens.").

72. MARK A. GRABER, DRED SCOTT AND THE PROBLEM OF CONSTITUTIONAL EVIL 57 (2006).

73. Dred Scott, 60 U.S. (19 How.) at 407, 410 (quoting THE DEClaRATION OF INDEPENDENCE para. 2 (U.S. 1776)). 
In Taney's view, a "free" black was just a slave who happened to temporarily lack an individual master and therefore was owned by the white community as a whole. Or, to be fair, this was Taney's view of the Framers' prejudices that was implicitly enshrined in the Constitution. In Taney's words:

[A] perpetual and impassable barrier was intended to be erected between the white race and the one which they had reduced to slavery, and governed as subject with absolute and despotic power, and which they then looked upon as so far below them in the scale of created beings, that intermarriages between white persons and negroes or mulattoes were regarded as unnatural and immoral .... And no distinction in this respect was made between the free negro or mulatto and the slave, but this stigma, of the deepest degradation, was fixed upon the whole race. ${ }^{74}$

Furthermore, Taney said that at the time of the Founding, blacks were separated from whites "by indelible marks, and laws long before established, and were never thought of or spoken of except as property, and when the claims of the owner or the profit of the trader were supposed to need protection." 75 In short, in the single most remembered phrase from Taney's opinion, blacks were regarded as "so far inferior, that they had no rights which the white man was bound to respect.",76

This vision of free blacks as having little more status than slaves was approximately correct in slave states in Taney's own time. As Fehrenbacher says:

Black "freedom" in a slaveholding state, however, was in many respects little more than a special category of slavery. The southern free Negro lived in a precarious world cramped between two fairly distinct boundaries-the legal line separating him from the great mass of blacks and the color line separating him from the great mass of free men. More often than not, it was the color line that determined his status and treatment in any specific circumstance. ${ }^{77}$

Fehrenbacher observes that, in Taney's time, "[i]ncreasingly, free Negroes were equated with slaves in southern law"78 and were subject to the risk of involuntary servitude. ${ }^{79}$ Thus Taney's view of non-slave blacks as enjoying

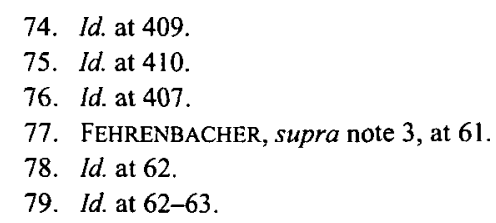


only a simulacrum of freedom was consistent with antebellum Southern views.

But, whatever may have been true in Taney's time, there really was no evidence that the Framers collectively viewed free blacks as being outside the social compact. Memorably, Jefferson's draft of the Declaration of Independence accused the King of waging "cruel war against human nature itself, violating it's [sic] most sacred rights of life and liberty in the persons of a distant people who never offended him, captivating \& carrying them into slavery in another hemisphere, or to incur miserable death in their transportation thither." ${ }^{, 80}$ Indeed, the evidence cited by the dissenters showed that blacks were treated to a considerable extent as members of the legal and political community in many places, even if generally not as fully equal members. For instance, according to the Supreme Court of North Carolina, at the time of the Framing:

Slaves manumitted here became freeman-and therefore if born within North Carolina are citizens of North Carolina-and all free persons within the State are born citizens of the state... [I]t is a matter of universal notoriety that ... free persons, without regard to colour, claimed and exercised the franchise until [the state constitution was amended]. ${ }^{81}$

Unfortunately, Taney's willingness to read his own racism into the Constitution did not die with him or even with the formal grant of citizenship to blacks under the Fourteenth Amendment. ${ }^{82}$ After the Civil War, it did not take long for the Court to embrace racist assumptions again in Plessy v. Ferguson, where the Court upheld the power of states to treat blacks as untouchables. ${ }^{83}$ It was not until Brown v. Board of Education, a century after Dred Scott, that the Court finally embraced racial equality. ${ }^{84}$

80. Thomas Jefferson, A Declaration by the Representatives of the United States of America, in General Congress Assembled, in THOMAS JEFFERSON, AUTOBIOGRAPHY 1743-1790, reprinted in THOMAS JEFFERSON: WRITINGS 22 (Merrill D. Peterson ed., 1984).

81. State v. Manuel, 20 N.C. (3 \& 4 Dev. \& Bat.) 144, ${ }^{*} 25$ (1838).

82. U.S. CONST. amend. XIV, $\S 1$.

83. Plessy v. Ferguson, 163 U.S. 537 (1896), overruled by Brown v. Bd. of Educ., 347 U.S. 483 (1954).

84. Brown, 347 U.S. 483. 


\section{B. Narrow Reading of the Enumerated Powers}

Taney also held that Congress had no power to regulate slavery in the territories. His route to this conclusion was peculiar. The Property Clause unmistakably gives Congress regulatory power over U.S. territories. It provides that "Congress shall have Power to dispose of and make all needful Rules and Regulations respecting the Territory or other Property belonging to the United States." 85 Chief Justice Marshall had emphasized the sweep of federal powers over the territories:

The power of governing and of legislating for a territory is the inevitable consequence of the right to acquire and to hold territory. Could this position be contested, the constitution of the United States declares that "congress shall have power to dispose of and make all needful rules and regulations respecting the territory or other property belonging to the United States." Accordingly, we find congress possessing and exercising the absolute and undisputed power of governing and legislating for the territory of Orleans. ${ }^{86}$

The Property Clause seems to easily encompass the power to regulate slavery in the territories, but that interpretation would have been inconvenient for Taney for two reasons. First, it would have made the congressional reenactment of the Northwest Ordinance, with its ban on slavery, a clear precedent for the Missouri Compromise. Taney needed a theory that distinguished Congress's power over territories held when the Constitution went into effect from territories acquired later. Second, the Property Clause contains no special requirement of equal treatment between the interests of various states, but Southerners insisted that the territories needed to be governed in a way that respected their interests.

Thus, it was important for Taney to find some way of taking the Property Clause off the table. In an amazing leap, Taney concluded that the clause only applied to territories that were held by the United States when the Constitution went into effect. ${ }^{87}$ Instead, in another leap of creativity, he said that the federal government derived its power over territories by implication from the congressional power to admit new states into the union, which carried an implicit requirement that all of the existing states were to be equally respected in adding new territory. ${ }^{88}$

85. U.S. CONST. art. IV, $\S 3$, cl. 2.

86. Sere v. Pitot, 10 U.S. (6 Cranch) 332, 336-37 (1810).

87. Dred Scott v. Sandford, 60 U.S. (19 How.) 393, 436 (1857).

88. Id. at $443-44$. 
Taney tied these conclusions to a vision of limited government. Because the federal government possesses only "certain enumerated and restricted powers," it can only acquire new territory "for the benefit of the people of the several States who created it," acting as "their trustee." 89 For Taney said:

The principle upon which our Governments rest, and upon which alone they continue to exist, is the union of States, sovereign and independent within their own limits in their internal and domestic concerns, and bound together as one people by a General Government, possessing certain enumerated and restricted powers, delegated to it by the People of the several States ... ${ }^{90}$

Thus, the federal government's powers over territories are intrinsically limited:

Whatever [the federal government] acquires, it acquires for the benefit of the people of the several States who created it. It is their trustee acting for them, and charged with the duty of promoting the interests of the whole people of the Union in the exercise of the powers specifically granted. ${ }^{91}$

Taney speculated that the Property Clause was only meant to apply to the property and territory that various states owned or ceded to the Continental Congress at the time the Constitution went into effect. These were tenuous arguments in the absence of any specific evidence. It is striking that these pages of the opinion are almost bereft of citations to judicial authority or historical sources. Taney seemed to feel free to speculate without evidence about what the Framers had in mind in order to import a temporal limitation on a provision that on its face is permanent.

Anyone can play that game. If the Property Clause can be read to apply only to property owned at the time the Constitution went into effect, why not other parts of the Constitution - say, the Fugitive Slave Clause? On this interpretation, just as Taney thought the Property Clause meant "the Territory or other Property [now] belonging to the United States," ${ }^{, 92}$ the Fugitive Slave Clause would have applied to any "Person [now] held to

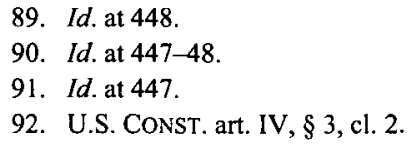


Service or Labour in one State." ${ }^{\text {"93 }}$ This may seem an audacious reading of the Fugitive Slave Clause, but the arguments for that interpretation are only a little weaker than Taney's interpretation of the Property Clause.

Just as Taney did with the Property Clause, one could point to special historical circumstances at the time of the Framing that might have been the unspoken subject of the Fugitive Slave Clause. The American Revolution separated slaves from their masters or allowed them to escape in the confusion of the war, and even worse, from the Southern perspective, the British promised freedom to blacks who joined their side. It would have made sense to provide a special, temporary remedy for the affected slave owners as part of the general effort to settle land, debt, and property disputes arising from the war.

As with Taney's interpretation of the term "citizenship," one might also support this interpretation of the Fugitive Slave Clause with speculation about the views of the Framers. Surely, one might argue, Northern whites would not have been willing to accept as a permanent matter the degrading duty-indeed, one might say, servile duty-of fetching slaves at the command of masters who had been too careless to control their own property. And surely Southern slave owners would not have thought that the number of slaves who could escape and travel all the way north during normal peacetime conditions would be large enough to warrant a special constitutional provision.

Indeed, in support of the idea that the clause meant to deal only with a limited, temporary problem, one might point out that it did not encompass slaves who escaped from the territories or the District of Columbia (because in those places they were not "held to service" under any state law), nor did it include Southern slaves who escaped to a federal territory or the District of Columbia. So it obviously was not intended to provide any comprehensive remedy to the owners of escaped slaves. How much more reasonable to interpret it as a part of the post-Revolutionary War settlement of claims and debts by the federal government.

Admittedly, these are not convincing constitutional interpretations, but the reasoning follows the same lines as Taney's and is only slightly less plausible than his view that "the Territory or other Property belonging to the United States" meant only that property owned in $1789.9^{94}$ Fehrenbacher accurately says that it is difficult to take Taney's argument seriously. ${ }^{95}$ Rather than legal analysis, however, Taney's opinion seems primarily to reflect his desire to strike a decisive blow for the South. Before Buchanan's election, he had already worried that the South was "doomed to sink to a state of inferiority, and the power of the North will be exercised to gratify

93. U.S. ConsT. art. IV, $\S 2$, cl. 3.

94. Dred Scott, 60 U.S. (19 How.) at 436.

95. FEHRENBACHER, supra note 3 , at 367. 
their cupidity and their evil passions, without the slightest regard to the principles of the Constitution. ${ }^{196}$

The absurdity of Taney's reasoning is revealed by two key facts. First, at the same time that the Constitution was being drafted, Congress passed the Northwest Ordinance, which prohibited slavery in what is now the American Midwest. Second, after the Constitution went into effect, "the Northwest Ordinance was re-enacted by a Congress that included many of the framers, and there was no resistance on constitutional grounds. ${ }^{, 97}$ Indeed, the present-day revisionists, who are seeking to rehabilitate the decision, seem to have made no effort to defend his tortured approach to the Property Clause. ${ }^{98}$

Nothing of Taney's interpretation remains in current law. In Kleppe $v$. New Mexico ${ }^{99}$ the Supreme Court made clear the breadth of the Property Clause and its applicability to all federal property and territories:

It is the Property Clause, for instance, that provides the basis for governing the Territories of the United States. And even over public land within the States, "[t]he general government doubtless has a power over its own property analogous to the police power of the several States, and the extent to which it may go in the exercise of such power is measured by the exigencies of the particular case."... In short, Congress exercises the powers both of a proprietor and of a legislature over the public domain. Although the Property Clause does not authorize "an exercise of a general control over public policy in a State," it does permit "an exercise of the complete power which Congress has over particular public property entrusted to it." 100

Although Taney's interpretation of the Property Clause was quickly forgotten, his strategy of reading Congress's enumerated powers narrowly was prophetic. In a series of cases in the late nineteenth century and early twentieth century, the Court held that Congress lacked the power to regulate the economy. Like Taney, these later Justices were eager to limit federal

96. 5 CARL B. SWISHER, THE OLIVER WENDEll Holmes DeVISE History OF THE SUPREME COURT OF THE UNITED STATES: The TANEY PERIOD, 1836-64, at 609 (1974).

97. FEHRENBACHER, supra note 3, at 370.

98. See Paul Finkelman, Was Dred Scott Correctly Decided? An "Expert Report" for the Defendant, 12 LEWIS \& CLARK L. REV. 1219, 1237 (2008).

99. 426 U.S. 529 (1976).

100. Id. at $539-40$ (citations omitted). 
power in order to protect their favored economic arrangements from potential interference by national majorities.

\section{Constitutional Protection for Property Rights}

Taney was at pains to show that Congress had no power to interfere with the rights of private property. After reciting the protection of free speech and other individual rights, he added that "the rights of private property have been guarded with equal care." 101 He continued: "Thus the rights of property are united with the rights of person, and placed on the same ground by the $[\mathrm{F}]$ ifth $[\mathrm{A}]$ mendment to the Constitution, which provides that no person shall be deprived of life, liberty, and property, without due process of law." ${ }^{102}$ Hence, he concluded:

[A] $n$ act of Congress which deprives a citizen of the United States of his liberty or property, merely because he came himself or brought his property into a particular Territory of the United States, and who had committed no offence against the laws, could hardly be dignified with the name of due process of law. ${ }^{103}$

Taney was determined to sweep beyond any issue actually presented in the case in asserting the constitutional right to hold slaves. He hinted that slave owners were entitled to the enactment of federal slave codes, saying that it was a congressional "duty to establish" legal rules "that would be best suited for the protection and security of the citizens of the United States"104_-presumably including protection and security for their property. He also made it clear that territorial legislatures had no greater powers than Congress to regulate slavery:

And if Congress itself cannot do this-if it is beyond the powers conferred on the Federal Government-it will be admitted, we presume, that it could not authorize a Territorial Government to exercise them. It could confer no power on any local Government, established by its authority, to violate the provisions of the Constitution. $^{105}$

Of course, this issue was not remotely before the Court, but Taney took advantage of the occasion to take a swipe at the Douglas "popular

101. Dred Scott v. Sandford, 60 U.S. (19 How.) 393, 450 (1857).

102. Id.

103. Id.

104. Id. at 449.

105. Id. at 451 . 
sovereignty" wing of the Democratic Party in order to strengthen the position of the more extremist wing.

Whether the Due Process Clause provides protection against the substance of legislation, as opposed to the right to a hearing, remains hotly disputed today. Still, the modern Supreme Court has continued to view the clause as providing substantive protection to property and liberty. Even so, it is a bit of a stretch to say that due process protects the right to possess property in a territory if it is legal to possess it anywhere in the Union. On this theory, the government would have no constitutional power to ban marijuana in Guam since its possession for medicinal purposes is legal in California. Even more sweepingly, one could make the same "least common denominator" argument regarding liberty, so that Congress could regulate conduct in the territories or in the District of Columbia only if that conduct was unlawful in every single state of the Union.

Thus Taney's theory seems dubious as applied to other kinds of property. Apart from the Fugitive Slave Clause, which applies only in limited circumstances, there is nothing in the Constitution that gives slavery a higher status than any other form of property. But equating slaves with other forms of property is misleading. By equating slaves with other property for purposes of due process, Taney overlooked the fact that the Constitution treats them both as property and as persons, as well as the special treatment that the legal system had always given the slavery issue. Indeed, the Fugitive Slave Clause itself seems more akin to the companion clause requiring states to extradite fugitives from justice, rather than being a property protection.

At the heart of Taney's argument that a free territory would deprive a slaveholder of property was the assumption that territorial law would otherwise recognize the slave relationship. This was in effect a constitutional choice-of-law rule, holding that slave status was governed by the state in which the alleged owner and slave had previously been domiciled, even if they now assumed a domicile in a jurisdiction that did not explicitly recognize slavery. As discussed earlier, this choice-of-law rule was not generally recognized in the United States or elsewhere, going back to the Somerset case. ${ }^{106}$ Rather, the rule was that the slave relationship was purely a creature of local statute. This rule had been adopted by the Supreme Court itself in Prigg v. Pennsylvania, ${ }^{107}$ where Justice Story's

106. Somerset v. Stewart, (1772) 98 Eng. Rep. 499 (K.B.).

107. 41 U.S. (16 Pet.) 539 (1842). Other aspects of Prigg are critiqued in Paul Finkelman, Story Telling on the Supreme Court: Prigg v. Pennsylvania and Justice Joseph Story's Judicial Nationalism, 1994 SUP. CT. REV. 247. 
majority opinion took the position that the "state of slavery is deemed to be a mere municipal regulation, founded upon and limited to the range of the territorial laws" and recognized elsewhere only on the basis of comity. ${ }^{108}$ Thus, when an owner took a slave into a jurisdiction that did not recognize slavery, he had no vested property right that was entitled to local recognition.

Recall that the Constitution and the Bill of Rights were contemporaneous with the passage of the Northwest Ordinance and its statutory reaffirmation under the new Constitution - an action that according to Taney violated the Due Process Clause. It is hard to dispute historian Kenneth Stampp's appraisal: "A restriction thus imposed on congressional power to govern the territories, unmentioned in the Constitution, unknown to its framers, undiscovered for many years thereafter, but recently devised by John C. Calhoun and other proslavery partisans, was now, according to the opinion of the Court, the law of the land." 109

\section{EVALUATING DRED SCOTT}

Dred Scott $v$. Sandford has a singular position in the history of the Supreme Court. Many judicial decisions are failures, like many other human actions. But no other decisions contrived to fail across so many different dimensions - as an exercise in judicial overreaching, intellectual dishonesty, and disastrous statesmanship - and to do so in the defense of an institution whose very existence was a violation of human rights.

\section{A. Constitutional Justification}

There is little reason to think that at the time the Constitution was framed, Americans understood the term "citizens of the several states" to mean any person born or naturalized in the United States who inhabits a state except one who was a former slave or any of whose ancestors had ever been a slave. Nor is there any reason to believe that they understood "territories" to mean land owned at that time by the United States rather than acquired later, or a "deprivation" of property to include a restriction on moving property across jurisdictional lines. Thus, the original understanding of constitutional terminology provides little support for Taney's opinion.

What about a non-originalist justification? There is no consensus about how to conduct a non-originalist analysis, but a partial list would include the considerations of text and history that have already been discussed, precedent, societal consensus, developing social trends, moral judgments,

108. Prigg, 41 U.S. (16 Pet.) at 612.

109. KENNETH M. STAMPP, AMERICA IN 1875: A NATION ON THE BRINK 96 (1990). 
and pragmatic considerations. ${ }^{110}$ Of this list, the last two are the most controversial and are the weakest reeds when lacking support from the others.

Taney clearly was not building on prior Supreme Court authority in a common law manner-substantive due process was a novel concept for the Court, the interpretation of the Property Clause contradicted dictum by Chief Justice Marshall, and the citizenship holding did not rest on earlier Supreme Court analyses of citizenship. State and lower federal court holdings had split into Northern and Southern approaches to slavery issues, with the Southern courts moving away from earlier doctrines that still had support in the North. Certainly, there was nothing like a consensus for the Court to build on, or even a nationwide trend. Internationally, the movement was against slavery, as shown by British abolition of the slave trade.

This leaves us with the morality issue and pragmatic factors ("statesmanship"). The moral issue does not need discussion. On the pragmatic side, the decision was at best unhelpful. As discussed in Part C, it undercut the popular sovereignty position of Stephen Douglas and fueled Republican anger. Taney's position that territories had to allow slavery until they applied for statehood was just an invitation for another Bloody Kansas, where violence between pro-slavery and anti-slavery factions had become a national flashpoint. But as we will see in the next section, the failure of statesmanship may have in part been due to the covert efforts of President Buchanan to influence the decision-and perhaps no one in U.S. history has ever had more disastrously bad judgment than James Buchanan.

\section{B. Legal Process Pathologies}

Dred Scott represents perhaps the greatest example of Executive intrusion into the Court's deliberations in U.S. history. On February 3, 1857, James Buchanan wrote to Justice Catron to find out when the decision would come down. ${ }^{111}$ Catron expected a decision in conference on February 14, but he wrote back on February 19 explaining that there were delays. ${ }^{112}$ He told Buchanan that he could say in his inaugural address that the Supreme Court was going to decide on the constitutionality of the Missouri Compromise. ${ }^{113}$ Catron also gave details about the views of individual

110. For a discussion and application of these approaches, see DANIEL A. FARBER, RETAINED BY THE PEOPLe: ThE "Silent" Ninth AMENDMENT AND the Constitutional Rights AMERICANS DON'T KNOW THEY HAVE (2007).

111. FEHRENBACHER, supra note 3 , at 307 .

112. Id. at 309.

113. Id. 
Justices. Justice Grier was also in communication with Buchanan. Buchanan wrote Grier, pressuring him to join the Southern majority so that the Court's decision would not appear too sectional. ${ }^{114}$

Buchanan duly urged citizens in his inaugural address to abide by the Court's decision, which he of course knew in advance would be favorable to slavery. ${ }^{15}$ Later, Buchanan again exploited the decision. In recommending the admission of Kansas as a slave state, he said that the Supreme Court had ruled "that slavery exists in Kansas by virtue of the Constitution of the United States," and that "Kansas is therefore at this moment as much a slave state as Georgia or South Carolina."116 According to Fehrenbacher, Taney and Buchanan may also have communicated beforehand on the issue of whether a territorial legislature could prohibit slavery, an issue that Taney was careful in his opinion to address to the detriment of the "popular sovereignty" approach of Senator Douglas. ${ }^{117}$

To add to the procedural irregularity, Taney refused to allow the dissenters to have a copy of the opinion of the Court ${ }^{18}$ and continued making secret revisions even after the decision was announced. Curtis contended that about eighteen pages were added to the opinion responding to the dissents, an assertion that seems to be correct. ${ }^{119}$ As a result, the "socalled opinion of the Court included a considerable amount of material that few if any of the other justices heard or read before its publication."120

No wonder the Republicans immediately proclaimed that the decision was the result of a conspiracy involving Buchanan and others. Seward viewed Buchanan as the mastermind behind the decision-an exaggeration, but as we have seen, not entirely unfounded. ${ }^{121}$

To add to the "legal process" flaws of the decision is the massive confusion about what the Court actually held. Taney labels his opinion as the opinion of the Court, but a number of other Justices wrote separately without clearly indicating what portions of his opinion, if any, they were joining. ${ }^{122}$ For instance, some historians believe that only three Justices agreed that a black could not be a citizen of the United States. ${ }^{123}$ Even today, the question remains disputed. As Fehrenbacher said, "efforts at

114. Id. at 309-12.

115. SWISHER, supra note 96 , at 615-19.

116. Id. at 649 .

117. FEHRENBACHER, supra note 3 , at 314.

118. SWISHER, supra note 96 , at 633-34, 659.

119. FEHRENBACHER, supra note 3 , at 320.

120. Id. at 320-21.

121. SWISHER, supra note 96 , at $647-48$.

122. FEHRENBACHER, supra note 3, at 322-23.

123. Id. at 324 . 
clarification by several generations of scholars have, in some respects, only added new levels of confusion."124

As Part $\mathrm{C}$ explains, we know now that Buchanan was on the verge of breaking with Douglas over the pro-slavery Lecompton Constitution for Kansas, and in fact he relied on Dred Scott to help justify his position. It may not be unduly paranoid to assume that he intended all along for the Court to help him undermine Douglas's platform of popular sovereignty.

\section{Practical Impact}

The end of the 1850 s found the nation poised on the brink of disaster. The Democratic Party was shattered by Southern demands that the party repudiate popular sovereignty and endorse a slave code. The Republicans had a strong base of support in the North. By nominating a moderate "westerner" like Lincoln, they could pick up Illinois and other swing states in the North. By the time it was actually held, the election of 1860 was almost a foregone conclusion. Although Lincoln was outvoted nationally by supporters of Douglas and other candidates, the Republicans' strength in the North gave them the Electoral College and the Presidency. Key figures in the South had already announced that living under a Republican president was utterly unacceptable to them. ${ }^{125}$

Even before the results were in, Southern fire-eaters had warned that Lincoln's election would dissolve the Union. The governor of South Carolina had opened correspondence in October with other Southern governors about ways and means of pursuing secession. Within three weeks of the election, conventions to consider secession were called in South Carolina, Alabama, Mississippi, Florida, and Georgia. In the early afternoon of December 20, the South Carolina convention voted to secede. Georgia, Mississippi, Florida, Alabama, Louisiana, and Texas followed by the end of January. Within another week or so, delegates from these states had met in convention, adopted a constitution closely modeled after that of the United States, and elected Jefferson Davis as provisional president. All this was accomplished well before Lincoln was scheduled to take office in March. ${ }^{126}$

Dred Scott cannot be called the cause of the Civil War. Such events have complex causes rather than a single trigger. Indeed, despite a widespread contrary impression, the decision did not have an immediate or

124. Id. at 323.

125. See 2 NEVINS, supra note 24, at 209-28, 272-76, 288-90; POTTER, supra note 22, at 407-16, 427-30, 439-40, 442-47.

126. 2 NEVINS, supra note 24 , at $318-28,359,417,433$. 
direct effect on secession. But Dred Scott certainly did nothing to bridge the differences between the two sections of the country. Instead, it handed a complete victory to one side. As a Georgia newspaper said at the time, the Court's opinion "cover[ed] every question regarding slavery and settle[d] it in favor of the South."127 Doing so could only strengthen Southern perception that their own side was entirely in the right and the other side completely misguided, thus increasing polarization. It also pushed the Republicans toward a more radical position, strengthening their "belief in a slavepower conspiracy." 128

As Paul Finkelman has said,

Most northerners found the decision shocking and immoral. Republicans attacked it with great effect in the political campaigns of 1857-1860. It doubtless helped Lincoln win the presidential election in 1860 . That in turn led South Carolina and eventually ten other states to abandon the United States and try to form their own country. That led to civil war. ${ }^{129}$

Indeed, according to Fehrenbacher, the Republican response "combined furious anger at the import of the decision with half-suppressed delight at its contemplated political effects."130 Northern Democrats suffered big losses in the 1858 elections, and "Lecompton and Dred Scott accounted for much of this Republican gain." 131

Although the decision initially received broad support from Democrats, ${ }^{132}$ Dred Scott was logically inconsistent with the views of the faction with the broadest national support headed by Stephen Douglas. Douglas favored territorial sovereignty on the issue of slavery. But Taney made it clear that territories had no power to ban slavery before admission to the Union. Lincoln attempted to exploit this in his famous Freeport question, although Douglas dodged the issue in his response by claiming that a territory could exclude slavery simply by failing to pass any laws to protect

127. FEHRENBACHER, supra note 3, at 449 .

128. MORRISON, supra note 23, at 189.

129. FINKELMAN, supra note 27 , at vii.

130. FEHRENBACHER, supra note 3 , at 450 . According to the leading historian of secession: The very great importance of Roger B. Taney was that he could not have flung a more hate-packed decree at the Republicans if he had been a zealot for perpetual enslavement and disunion. So too, the Southemers who made the so-called Dred Scott Decision (and the Border North's president-elect who begged them to save the Union) could not have better greased the nation's slide toward disunion if they had been Slave Power ultras.

2 William W. FREeHLING, THE ROAD to Disunion: SECESSIONISTS TRIUMPHANT, 1854-1861, at 121 (2007).

131. JAMES M. MCPHeRSON, BATtLe CRY OF FreEdom: THE CIVIL WAR ERA 188 (1988).

132. MORRISON, supra note 23 , at 189. 
it. ${ }^{133}$ This position proved unacceptable to the South; Southerners conceded as a practical matter that slavery needed support from local legal institutions, "[b]ut it was a different matter to have the acknowledgement thrown back at them as a constitutional principle by the man already widely accused of betraying the South."134 The Democratic convention broke apart over whether the platform should deny territorial power over slavery and demand a federal slave code for the territories. ${ }^{135}$

A recent revision view is that Dred Scott was a centrist decision that helped support the unity of the Democratic Party. ${ }^{136}$ Even the revisionists concede, however, that the opinion "did aggravate some tensions responsible for the Civil War." 137 Given Taney's vehemently pro-Southern attitude, it is difficult to accept the characterization of the opinion as a centrist enterprise, trying to mediate between opposing factions. If the opinion was centrist, what could Southerners possibly have wanted that they did not get from the Court? Note also that the revisionist view holds that Northern Republicans were not part of the spectrum of opinion that had to be accommodated in a compromise. ${ }^{138}$ The assertion seems to be that the opinion was a reasonable compromise among the various Democratic factions. If so, it was a compromise that went out of its way to reject the key element of Douglas's position: territorial sovereignty. ${ }^{139}$ Even within the Democratic party, the decision was not a compromise, but instead it was a total victory for the constitutional views of one wing of the party, and not surprisingly so given Buchanan's covert involvement in the decision.

The Court had other options open to it. It could have held that the prior Missouri judgment was res judicata, or that in any event Missouri law determined whether to give effect to Scott's prior residence in arguably free territory. It could have ruled solely on the citizenship issue while upholding Congress's power over the territories or avoiding that issue. We can only speculate about how any of these other options would have affected the course of events. But it is plausible to think that, for instance, a decision endorsing control by territorial legislatures over slavery might have boosted

133. FEHRENBACHER, supra note 3 , at 457.

134. Id. at 518 .

135. Id. at 534 .

136. See GRABER, supra note 72. For another effort to rehabilitate the pro-slavery vision, see Gerald Leonard, Law and Politics Reconsidered: A New Constitutional History of Dred Scott, 34 LAW \& SOC. INQUIRY 747 (2009).

137. GRABER, supra note 72 , at 39.

138. Id. at $39-40$.

139. Graber argues that territorial sovereignty was the least controversial approach to slavery in the territories. Id. at 43 . But Taney specifically held that popular governments lacked any authority to limit slavery. 
the acceptability of popular sovereignty as a solution, helping to hold the Democratic Party together as a non-sectional force, thereby avoiding the secession crisis. ${ }^{140}$

Even if, as revisionists argue, Dred Scott did not help bring on the war, it would still be notable as a symptom of the polarization that would soon lead to the war. Taney's opinion was an aggressive statement of the purist Southern position. Taney's unwillingness to rest the decision on narrower grounds and his insistence on addressing the issue of territorial sovereignty had little to do with the legal dimensions of the case and more to do with the rising demands of Southerners for absolute national adherence to their views. Rather than seeking a middle ground, Taney joined with the sectional forces that were pulling the country apart.

\section{DRED SCOTT AND JUDICIAL METHOD}

Even Carl Swisher, a great admirer of Taney, admitted that Dred Scott has "gone down in history as a major disaster." 41 Indeed, Dred Scott seems to have an unequaled supply of failings. On the legal process level, it featured illicit communications between the President and select Justices, followed by a refusal to allow dissenters to see the opinion. Its use of history was selective; its legal arguments were contrived; its holding a muddle. It tortured constitutional text, reading what amounted to an expiration date into the Property Clause. It rendered no less than three earthshaking constitutional innovations: the ineligibility of blacks for citizenship; the gutting of the Property Clause; and the creation of substantive due process-more or less the equivalent of three major constitutional cases like Miranda v. Arizona ${ }^{142}$ or Roe v. Wade ${ }^{143}$ wrapped into one. Worse, none of those three innovations, let alone all three together, were necessary to the decision of the case. ${ }^{144}$

At best Dred Scott was a symptom of the polarization that was soon to lead the country into civil war. But worse than that, it may actually have contributed to the march toward war by undermining popular sovereignty as a compromise and pushing Republicans to more extreme positions. And

\footnotetext{
140. See R. Kent Newmyer, The Supreme Court Under Marshall and Taney 141 (2d ed. 2006).

141. SWISHER, supra note 96 , at 631 .

142. 384 U.S. 436 (1966).

143. 410 U.S. 113 (1973).

144. The right term to describe Dred Scott seems less to be "activist" than "frenzied." The opinion evinces a complete lack of balance or restraint. To find a parallel, we have to imagine that Bush v. Gore, 531 U.S. 98 (2000), not only nuled in favor of Bush in the case before it but went out of its way to call Clinton's election invalid, or that Roe v. Wade, 410 U.S. 113 (1973), not only struck down abortion limitations at any point in pregnancy under the Due Process Clause but also went on to hold that medical services were outside the Commerce Clause and that pro-abortion speech was unprotected by the First Amendment.
} 
worst of all, these flawed actions were done in the service of the institution of slavery.

In methodological terms, Dred Scott was self-consciously originalist. Taney stressed that the Constitution "must be construed now as it was understood at the time of its adoption." 145 He continued:

It is not only the same in words, but the same in meaning ... and as long as it continues to exist in its present form, it speaks not only in the same words, but with the same meaning and intent with which it spoke when it came from the hands of its framers, and was voted on and adopted by the people of the United States. ${ }^{146}$

Any other approach, Taney argued, "would abrogate the judicial character of this court, and make it the mere reflex of the popular opinion or passion of the day." 147 Taney was not a particularly skilled originalist, and perhaps an originalist judge who was a better historian would have reached different conclusions. But Dred Scott raises some real questions about originalism. If Dred Scott was correct on originalist grounds, originalism looks morally questionable at least when the original understanding is tied up with earlier prejudices such as racism and sexism. On the other hand, if Dred Scott was wrong on originalist grounds, it seems to weaken the claim that originalism can restrain judicial willfulness.

Perhaps it is unfair to hold the result in Dred Scott against originalism as a methodology any more than the example of Hitler is a fair criticism of vegetarianism. But Dred Scott does illustrate three inter-connected pitfalls of originalism. The first is the natural tendency to read one's own views into the historical record. It is easy for anyone to fasten upon historical evidence that fits a preconceived vision, and given our training as advocates, lawyers and judges are probably more prone to this fault than historians.

The second pitfall is the failure to acknowledge that our evidence of the past is often incomplete and points in different directions, so that one must exercise a degree of humility in drawing conclusions. This is a lesson, one hopes, that professional historians learn in graduate school, but few judges have training in history. Judges and lawyers in general seem to find the lessons of history clear to an extent that seems oblivious to the fragmentary nature of the historical record.

145. Dred Scott v. Sandford, 60 U.S. (19 How.) 393, 426 (1857).

146. Id.

147. Id. 
Finally, and most fundamentally, it is often not merely the evidence but the historical reality that is ambiguous. The attitudes of the Framing generation toward slavery were not only varied among individuals but often profoundly complex and conflicted in the case of a single individual; the same Jefferson who could say of slavery that he "tremble[d] for [his] country when [he] reflect[ed] that God is just"148 could also abuse his position as master to have an affair with one of his own slaves.

Those who see the original Constitution and the legal system of its time as unambiguously pro-slavery have been eager to defend the logic of Taney's opinion. There is no blinking at the fact that the Constitution contained pro-slavery provisions. But it is another thing to jump to the conclusion that the entire Constitution needs to be given a pro-slavery reading. The legal system of the time - up to the years before the Civil War-treated slavery as a distinctive institution that posed problems quite different from other forms of property. Southerners won concessions in the drafting of the Constitution, but the Constitution was not designed purely for the purpose of defending the interests of slaveholders.

The Constitution's compromise with slavery is a blot on our history. The revisionists are right to insist on the significance of that fact and the ways in which this compromise infected the American constitutional order. But Taney's opinion turned that compromise into an unqualified victory for slavery, losing any of the sense of compromise and balance implicit in the original Constitution. Given the Southern demand to give the greatest possible protection to slavery in an increasingly hostile world, every provision of the Constitution had to be interpreted as slavery friendly. But this attributes a singularity of purpose and a rigorous coherence to a document that necessarily had to meet many different needs, and as in Taney's tortured interpretation of the Property Clause, it required reading implicit limitations into seemingly unambiguous language.

Antebellum Southern constitutionalism exemplifies a certain kind of foundationalism, which seeks to provide the Constitution with a foundational principle that would harmonize all of its provisions. This kind

148. Thomas Jefferson, Query $X V I I I$, in THOMAS JeFFERSON, NOTES ON THE STATE OF VIRGINIA, reprinted in THOMAS JEFFERSON: WRITINGS 289 (Merrill D. Peterson ed., 1984). He also reflected: And can the liberties of a nation be thought secure when we have removed their only firm basis, a conviction in the minds of the people that these liberties are of the gift of God? That they are not to be violated but with his wrath? Indeed I tremble for my country when I reflect that God is just: that his justice cannot sleep for ever: that considering numbers, nature and natural means only, a revolution of the wheel of fortune, an exchange of situation, is among possible events: that it may become probable by supernatural interference! The Almighty has no attribute which can side with us in such a contest.

Id. 
of foundationalism is endemic in constitutional discourse. ${ }^{149}$ In the case of Taney and Calhoun, that principle was equal treatment of the slave states; today, it might be protection for economic liberty for some writers ${ }^{150}$ or egalitarianism for others. ${ }^{151}$ Perhaps this is an indication of the strength of the dangerous pull toward absolute consistency and coherence and its risks for constitutional thinkers. Constitutions are not philosophical treatises; they are practical agreements about governance among people with diverse viewpoints. Trying to bring all of the Constitution into complete harmony loses sight of the need for a viable constitutional scheme to balance opposing interests and viewpoints.

Having a sense of balance is a prosaic, unexciting trait that we often take for granted. It is only when that sense of balance is completely lacking that we realize its importance. Dred Scott shows what can happen when a judge loses his balance at a critical moment. The case's aftermath shows what can happen, far more disastrously, when the same thing happens to a nation's politics.

149. For a discussion of foundationalism, see DANIEL A. FARBER \& SUZANNA SHERRY, Desperately Seeking Certainty: The Misguided Quest for CONSTITUTIONAL Foundations (2002).

150. See generally Richard A. EPSTEIN, TAKIngs: PRIVATE PROPERTY AND THE POWER OF EMINENT DOMAIN (1985).

151. See generally RONALD DWORKIN, LAW'S EMPIRE (1986). 
*** 